\title{
A case of three synchronous primary lung cancers within the same lung lobe
}

\author{
Szymon Wcisło, Piotr Misiak, Marian Brocki \\ Department of Thoracic Surgery, General Surgery and Oncology, Medical University of Lodz, Lodz, Poland
}

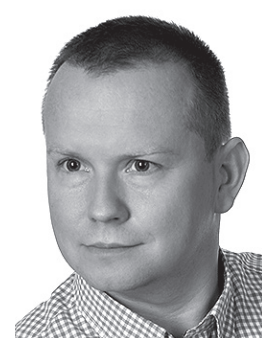

Kardiochirurgia i Torakochirurgia Polska 2016; 13 (2): 154-156

\begin{abstract}
We present the case of a 74-year-old patient with three synchronous primary lung cancers within the same lung lobe. Computed tomography and positron emission tomography investigations revealed two suspicious nodular lesions in the upper lobe of the left lung. Fine-needle aspiration biopsy confirmed that one of the lesions was non-small cell lung cancer. The patient was qualified for surgical treatment, and left upper lobectomy plus lymphadenectomy was performed. Histopathological examination confirmed the presence of three primary cancers in the left lung: keratinizing squamous cell carcinoma, neuroendocrine carcinoma, and acinar adenocarcinoma, localized within the same lung lobe. The patient was classified as having stage T3N1MO lung cancer (stage IIIA) according to the latest, $7^{\text {th }}$ edition of the TNM classification.

Key words: lobectomy, lung cancer, multiple tumours.
\end{abstract}

\section{Introduction}

Synchronous multiple primary lung cancers are reported rarely and account for about $8 \%(0.2 \%$ to $20 \%)$ of all lung cancers $[1,2]$. Patients with two or more lung tumours always require thorough diagnostics and an individually planned treatment procedure due to the nature of nodular lesions in the lung. Pulmonary metastases occur most frequently. Two primary lung cancers are rarely reported, but triple primary lung cancers are almost unheard of, and there has been just a single report from England describing a patient with this condition (2011). The authors successfully treated the patient surgically (right upper lobectomy), and post-operative histopathological examination revealed squamous cell carcinoma, adenocarcinoma, and adenomatous hyperplasia [3].

\section{Case report}

The 74-year-old patient with multiple primary lung cancers within the left lung was admitted to the Thoracic, General and Oncology Surgical Clinic in 2013. On interview, the patient reported fatigue and about $8 \mathrm{~kg}$ loss of body weight within 6 months. The patient did not report any oth-

\section{Streszczenie}

W pracy omówiono przypadek 74-letniego pacjenta z trzema wspótistniejącymi pierwotnymi nowotworami płuc zlokalizowanymi w obrębie tego samego płata. Badania tomografii komputerowej oraz pozytonowej tomografii emisyjnej wykazały dwie podejrzane zmiany guzowate w górnym płacie lewego płuca. Biopsja aspiracyjna cienkoigłowa potwierdziła w jednej ze zmian obecność niedrobnokomórkowego raka płuca. Pacjenta zakwalifikowano do leczenia chirurgicznego i wykonano u niego lobektomię górnego płata płuca lewego wraz z limfadenektomią. Badanie histopatologiczne potwierdziło obecność trzech pierwotnych nowotworów w lewym płucu: rogowaciejącego raka płaskonabłonkowego, nowotworu neuroendokrynnego i gruczolakoraka, zlokalizowanych w obrębie tego samego płata płuca. Pacjenta sklasyfikowano jako chorego na nowotwór płuca w stopniu zaawansowania klinicznego IIIA z cechą T3N1M0 według aktualnego 7. wydania klasyfikacji TNM.

Słowa kluczowe: lobektomia, nowotwór płuc, guzy rozsiane.

er ailments, but had been suffering from hypertension and COPD, and reported smoking for 60 years, 20 cigarettes per day. The patient underwent bronchoscopy, but it did not confirm any pathology suggesting a neoplastic process in the bronchial tree. Neoplastic cells were not found in the bronchoalveolar lavage fluid. Computed tomography investigation revealed two nodular lesions in the left lung. The first lesion, $41 \times 21 \mathrm{~mm}$ in size, was located in segments 1 and 2, and the second lesion, $31 \times 19 \mathrm{~mm}$ in size, was found in segment 3 of the left lung (Figs. 1 A, B). Tomographic imaging revealed lesions suspicious for cancer, group 5 lymph nodes up to $13 \mathrm{~mm}$, and left hilum up to $12 \mathrm{~mm}$. An image from the abdominal ultrasound scan revealed no significant abnormalities, apart from a left kidney cyst, $28 \times 19 \mathrm{~mm}$ in size. The patient was referred for FDG-PET scanning (positron emission tomography with ${ }^{18} \mathrm{~F}$ fluorodeoxyglucose (FDG)) and for determination of the standard uptake value (SUV), providing indirect diagnosis of pulmonary and other neoplastic tumours. In the upper lobe of the left lung investigations revealed a metabolically active tumour between segments 1 and 2 , with a maximum 

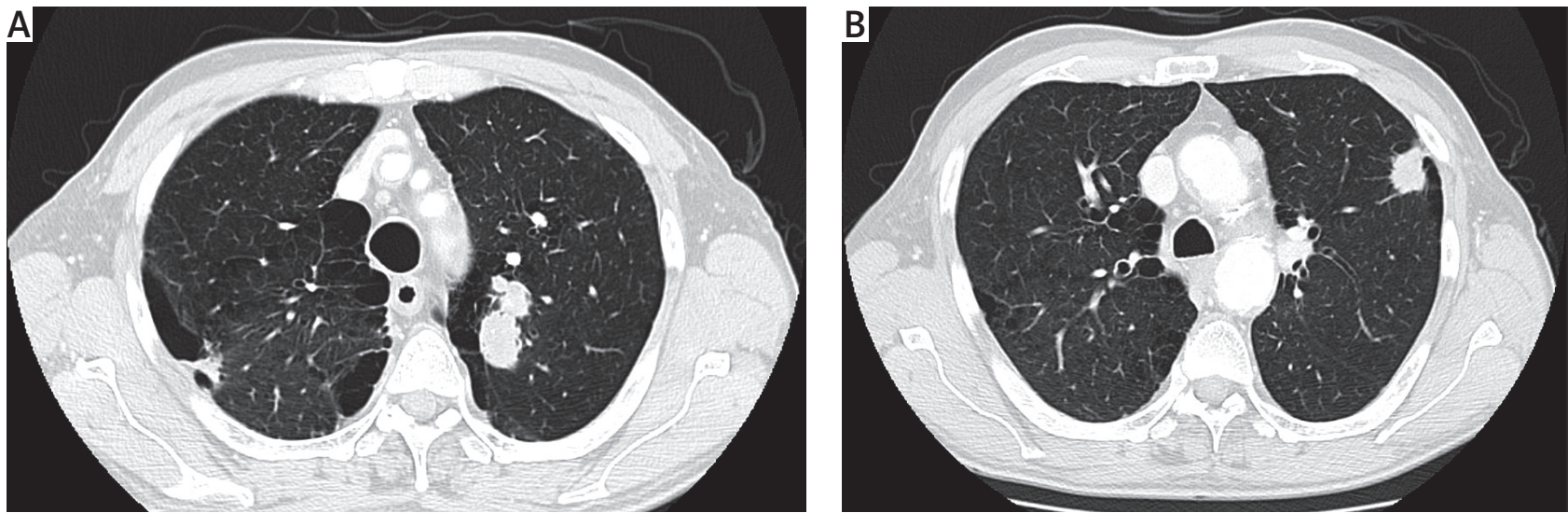

Fig. 1 A, B. Computed tomography scan - nodular lesions in the left lung
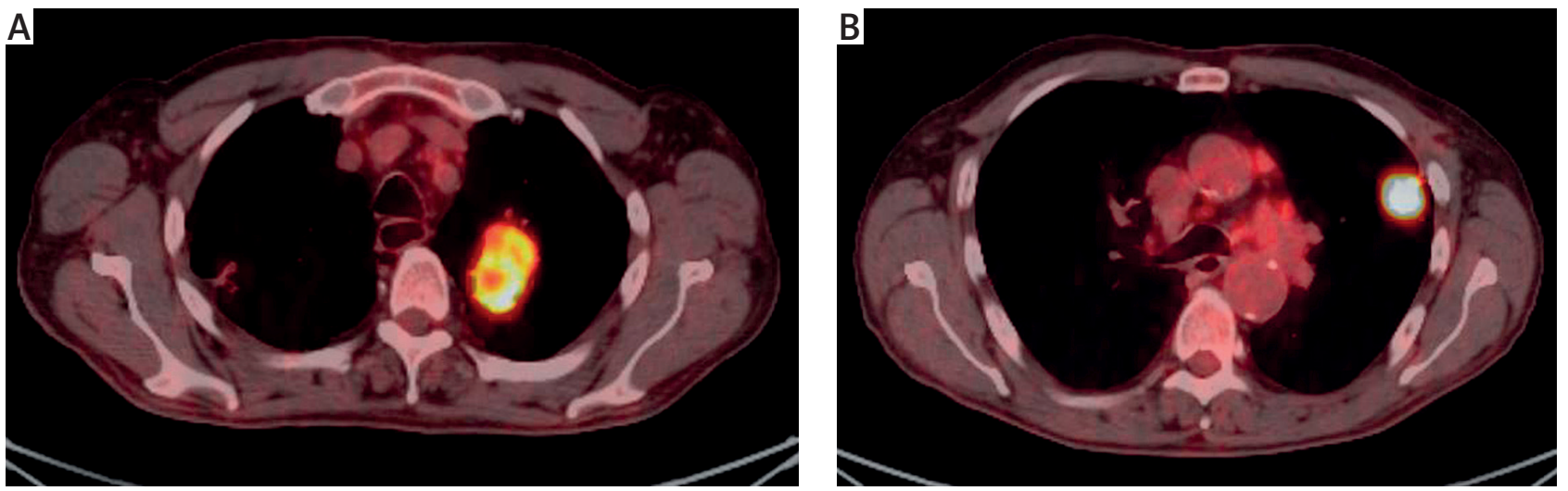

Fig. 2 A, B. Positron emission tomography scan - neoplastic tumours in the left lung

diameter of $42 \mathrm{~mm}$ and $\mathrm{SUV}_{\text {max }}$ FDG $=12.5$. The second metabolically active tumour was detected in segment 3 of the left lung and had a maximum diameter of $21 \mathrm{~mm}$ with SUV $_{\max }$ FDG $=25.6$ (Figs. 2 A, B). Similar to findings from computed tomography, metabolically active lymph nodes were detected with SUV max $_{\text {FDG }}=6.6$. No abnormalities associated with elevated FDG metabolism were found in other scanned parts of the body. Fine-needle aspiration (FNA) biopsy indicated non-small cell lung cancer. The patient was qualified for surgical treatment of lung cancer. In September 2013 the patient underwent left upper lobectomy plus lymphadenectomy under general anaesthesia and single-lung ventilation. Intraoperative findings confirmed the presence of the previously described lesions within the upper lobe of the left lung, and small lymph node groups $5,6,10$ and 11 l, which were resected. There were no postoperative complications. On the second and third day after surgery, drains were gradually removed from the pleural cavity and full lung expansion was achieved. On the fourth day after the surgery the patient was discharged and currently remains under the care of the thoracic surgery outpatient clinic affiliated with the hospital. Histopathological findings confirmed a tumour $30 \times 20 \times 20 \mathrm{~mm}$ in size in segment 3 , with the histopathological structure of keratinizing squamous cell carcinoma G2, and with immuno- histochemical profiles of p63 (+) and TTF1 (-). The second nodular lesion, $45 \times 35 \times 20 \mathrm{~mm}$ in size, was described by histopathologists as two lung cancers. The first part of it (90\%) consisted of neuroendocrine carcinoma G2 cells, with the immunohistochemical profile CD56 (+), CK7 (-), chromogranin (-), and synaptophysin $(-)$. The second part of the described nodular lesion (10\%) consisted of acinar adenocarcinoma $\mathrm{G} 2$ cells, with the immunohistochemical profile p63 (-) and TTF1 (+). In total, 12 lymph nodes were resected; of these, in 5, 6 and 11 I groups no metastases were found, and one out of two resected lymph nodes from group 10 I was found to be metastatic. All the three identified lesions were synchronous primary lung cancers.

\section{Discussion}

The synchronous occurrence of two primary lung cancers in the same lung was described for the first time by Beyreuther in 1924 [4]. In the literature there is a single case report, dated 2011, describing the occurrence of triple synchronous primary lung cancers, i.e. squamous cell carcinoma, adenocarcinoma, and adenomatous hyperplasia. The patient underwent lobectomy due to lesions present within a single lobe [3]. There have been other reports on multiple lung cancers. Recently, Finley et al. presented a case report describing the occurrence of multiple primary 
lung cancers. The researchers estimated that two primary lung cancers in the same lobe were diagnosed in $15 \%$ of all analysed patients $(n=175)$ [5]. The precise diagnosis of nodular lesions in lungs is crucial for the choice of further treatment method. Procedures used in patients with multiple metastatic lung cancers differ from those used in patients with multiple primary lung cancers. Positron emission tomography (PET) and computed tomography (CT) are very helpful diagnostic techniques for the preoperative assessment of patients. These techniques allow for the determination of the number, type and location of tumours within the body. Multiple lung cancers are usually metastatic, but their status can be confirmed by PET/CT scans $[6,7]$. Treatment options for patients with multiple and multifocal lung cancers remain controversial. In the described case examination results provided us with information on multiple metabolically active tumours within the same lung lobe. The choice of further procedure was clear, and we performed lobectomy plus lymphadenectomy. Nevertheless, the final confirmation of the lesion type is still provided by histopathological examination. Studies evaluating the survival of patients after procedural treatment for multiple lung cancers demonstrated much better outcomes in patients treated surgically for two synchronous primary lung cancers in the same lobe compared to patients with cancer at stage IIIB or IV [8]. Our patient does not meet the criteria for parameters T4 and M1. The patient was classified as having stage T3N1M0 lung cancer (stage IIIA) according to the latest, $7^{\text {th }}$ edition of the TNM classification.

\section{Disclosure}

Authors report no conflict of interest.

\section{References}

1. Xue X, Liu Y, Pan L, Wang Y, Wang K, Zhang M, Wang P, Wang J. Diagnosis of multiple primary lung cancer: a systematic review. J Int Med Res 2013; 41: 1779-1787.

2. Martini N, Bains MS, Burt ME, Zakowski MF, McCormack P, Rusch VW, Ginsberg RJ. Incidence of local recurrence and second primary tumors in resected stage I lung cancer. J Thorac Cardiovasc Surg 1995; 109: 120-129.

3. Sepehripour AH, Nasir A, Rajesh S. Multiple synchronous primary tumours in a single lobe. Interact Cardiovasc Thorac Surg 2012; 14: 340-341.

4. Beyreuther H. Multipicate von carcinomen bei einem fall von sog. Schenecberger Lungenkrebs mit tuberculose. Virchows Arch 1924; 250: 230-243.

5. Finley DJ, Yoshizawa A, Travis W, Zhou Q, Seshan VE, Bains MS, Flores RM, Rizk N, Rusch VW, Park BJ. Predictors of outcomes after surgical treatment of synchronous primary lung cancers. J Thorac Oncol 2010; 5: 197-205.

6. Lee WK, Lau EW, Chin K, Sedlaczek O, Steinke K. Modern diagnostic and therapeutic interventional radiology in lung cancer. J Thorac Dis 2013; 5 (Suppl. 5): S511-S523.

7. Shreve $P$, Faasse T. Role of positron emission tomography-computed tomography in pulmonary neoplasms. Radiol Clin North Am 2013; 51: 767-779.

8. Martini N, Melamed MR. Multiple primary lung cancers. J Thorac Cardiovasc Surg 1975; 70: 606-612. 